JURNAL AL BAYAN: JURNAL JURUSAN PENDIDIKAN BAHASA ARAB

\title{
Musyrifah Strategy in the Management of Mutawassith Class on Mufrodat Material at Shabah Al-Lughah
}

\author{
Ri'ayatul Maziyah ${ }^{1}$, Arina Nur Jannah ${ }^{2}$, Isti Mufidah ${ }^{3}$, Zakiyah Arifa ${ }^{4 *}$ \\ ${ }^{1}$ Prodi Pendidikan Bahasa Arab Universitas Islam Negeri Maulana Malik Ibrahim Malang, Indonesia \\ ${ }^{2}$ Prodi Pendidikan Bahasa Arab Universitas Islam Negeri Maulana Malik Ibrahim Malang, Indonesia \\ ${ }^{3}$ Prodi Pendidikan Bahasa Arab Universitas Islam Negeri Maulana Malik Ibrahim Malang, Indonesia \\ ${ }^{4}$ Prodi Pendidikan Bahasa Arab Universitas Islam Negeri Maulana Malik Ibrahim Malang, Indonesia
}

Article History:

Received : March $10^{\text {th }}, 2019$

Revised : April 12 $2^{\text {th }}, 2019$

Accepted : May $10^{\text {th }}, 2019$

Published : June $1^{\text {st }}, 2019$

Keywords:

Management; Strategy; Teacher; Vocabulary

*Correspondence Address:

arifazakiyah@uin-malang.ac.id

\begin{abstract}
Classroom management in the Shabah al-Lughah program has many variations on each subject and meeting. But there are also problem mufrodat learning in the classroom that are overcome by the teacher variation of strategies. his study aims to determine the strategy and role of supervisor (musyrifah) in the process of mufrodat learning on the mutawassith class so that it was categorized as a good classroom management. The type of this research is qualitative descriptive researchobtained from interviews, observation, and documentation relating to the strategy and role of musyrifah in measuring mutawassith class on the mufrodatmaterial; thenit analyzed. The data sources in this study are the musyrifah who teach in the mutawassith class. The results of this study are; first, variations strategy of musyrifah on the management of the mutawassith class when the mufrodat learning isusingthe audiolingual, the grammatical, the direct, the question, and answer method and the discussion. Second, the role of musyrifah in the classroom is more often teachercentered, that ismusyrifah acts as an instructor, musyrifah arranges to seat, delivers material, minimizes the transition time, gives a clue when mahasantri mention mufrodat meaning. Musyrifah dominates speech while Learner-centered roles are rarely used. So the existence of this research can provide a solution for instructors of Arabic language to develop their strategies, so that the desired goals of mufrodat material can be achieved.
\end{abstract}

\section{Introduction}

Class management consist of two words, namely management and class. ${ }^{1}$ Management comes from the word management that means management, the process of using the resource effectively to achieve the target. In that management, there is a process that controls all the thing in the implementation and achievement of the

${ }^{1}$ Nurhadi Nurhadi And Maria Sanprayogi Ningsih, 'Implementasi Manajemen Kelas Di Mts Jabal Nurrohman Kasreman Kabupaten Ngawi Jawa Timur', Al-Asasiyya: Journal Of Basic Education, 2.1 (2017). 
objective. $^{2}$ While class mangement is a mangement of Sedangkan manajemen kelas adalah manajement of classroom arrangement in form of effective rules to maximize the students learning. ${ }^{3}$ According to the definition, it signed that a class that consists of a group of students and a teacher needs management to achieve the objective by some process of management until the implementation.

Among the objectives of the class, management is avoiding things that interfere with the learning process, helping students to take advantage of the time to study and reduce the time that is not oriented in the objective and prevent students from experiencing academic and emotional problems. ${ }^{4}$ By the objectives, it makes the class management as the right tools to make the class's members understand the material which is achieved from the learning indicator.

Each class that consists of students and teacher that has been ensured to have class management that is designed in such a way by the teacher or educator, as the objective to be achieved. Likewise with the class management found in the Shabah alLughah Arabic classes at the center of Ma'had al-Jami'ah UIN Maulana Malik Ibrahim Malang. In each class in girls' dormitory, there are around 20 mahasantri and a musyrifah. Musyrifah is a senior of mahsantri from the mahasantri who lived in a dormitory and she also as a tutor in Shabah al-Lughah class. Shabah al-Lughah class is formed since the mahasantri entered ma'had and classified become three levels, those are: al-Aly, Mutawassith and Mubtadi' level from the placement test.

al-Aly class which is consist of mahasantri who have been able to speak Arabic well, while Mutawassith class is consist of mahasantri who previously studied Arabic whose ability were under the al-Aly class. Mubtadi' class is a basic class who the member of the class is mahasantri who never learn Arabic yet. From the objectives of the class, it hopes that mahasantri able to learn, practice and communicate in Arabic well. This activity is a must activity that is held every Monday until Friday after the morning prayer.

\footnotetext{
${ }^{2}$ Mulyadi, Classroom Management (Malang: Uin-Malang Press, 2009).

${ }^{3}$ Dina Gasong, Belajar Dan Pembelajaran (Deepublish, 2018).

4 Nuryani Y Rustaman, 'Perkembangan Penelitian Pembelajaran Berbasis Inkuiri Dalam Pendidikan Sains', In Makalah Dipresentasikan Dalam Seminar Nasional Ii Himpunan Ikatan Sarjada Dan Pemerhati Pendidikan Ipa Idonesia Bekerjasama Dengan Fpmipa. Universitas Pendidikan Indonesia, Bandung, 2005, Pp. 22-23.
} 
This research was conducted in one of the girl's dormitories and one of the classes at the mutawassith level. Because the mutawassith class was the class that had the most part and the class's members have a higher enthusiasm than mubtadi' class. Whereas, the mutawassith member was faster and easier in understanding material. The reason of the researcher why chosen this strategy of musyrifah theme was because the strategy in managing class in Shabah al-Lughah program was variation, that used by the musyrifah to handle when the mufrodat learning and for making the activity more effective in the class and not seem monotonous, mahasantri would more comfortable and motivated to learn Arabic especially in mufrodat material.

Based on these explanations, the researcher would focus on: first, how the musyrifah strategy in learning mufrodat in mutawassith Shabah al-Lughah class? Second, how the role of musyrifah in managing mutawassith Shabah al-lughah class?

\section{Theoretical Support}

\section{Definition of Class Management}

Management is a process to achieve the organization objectives by implementing the main function in the activity, those are planning, organizing leading, and controlling. Thus, management is a continuous activity.

While class is a place that very dominant for the occurrence of a group of students in a learning process. ${ }^{5}$ Thus the class is very important for the students in determining the success of students. The effective classroom atmosphere is needed in achieving the objective of learning.

Class management is an action class that in the form of effective rules in implementing the learning process for the students. ${ }^{6}$ In class management, there is a view of facilities used. Those are teacher-centered dan learner-centered. ${ }^{7}$

Teacher-centered perspective, 1). It more emphasized on the creation and rules of implementation in controlling the students' action. 2) Students who are passive and obedient to the rules can weaken him in active learning, logical, and social knowledge construction. 3) The teacher is authorized to organize the students. 4). The main source in

\footnotetext{
${ }^{5}$ Nok Pasikha, 'Implementasi Manajemen Kelas Dalam Mengatasi Masalah Disiplin Siswa', Dialektika: Jurnal Pemikiran Dan Penelitian Pendidikan Dasar, 7.1 (2017), 55-67.

${ }^{6}$ Pasikha.

${ }^{7}$ Rustaman.
} 
this problem is the teacher is less assertive, the procedure and the rules are not clear and the voice is weak.

Learner-centered perspective, a) It more focus on the students needs in developing the relationship and self-organize. b) Guidance to the students to be more disciplined and not emphasizes external control. c) Teacher as a guide, facilitator, and coordinator for the students. d) Leads to an open model, namely the teacher is not responsible for what is in class e). The main source in this problem is a curriculum that is not relevance and more emphasizes to the strength and uniformity.

According to Edmud, Emmer and Everson in their research stated that the effort of the teacher in managing the class can produce a higher achievement of the students. This all because of the involvement of the students in the class, their attitude and the behavior of the students was not interfering the teacher activity and other students, and the efficient learning time.

The development of motivation, students interest in learning and the enjoyable learning atmosphere are determined by the teacher leadership quality. But, not only the teacher that full of responsibility in the class, but also they should have the responsible feeling to the class and grow the leadership soul. ${ }^{8}$ Essentially, each of individual is a leader for his self and other.

\section{The Component of Class Management}

In class management, there are some components, those are 1). Time, time is an important thing in carrying out individual action in doing a task. 2). Place is a room which very special to hold a students meeting, and there are some facilities to support the students in achieving the learning objectives. 3). People includes teacher and students, some of them are finishing their role while others doing the learning process in the class. 4). The material and the educational tool includes of the students' chairs and props available in the class.

\section{The Objectives and Strategy in Class Management}

Generally, the objective of class management is to prepare the facilities for some various learning activity and students' works in a social environment, emotional and

\footnotetext{
${ }^{8}$ Junita W Arfani And Sugiyono Sugiyono, 'Manajemen Kelas Yang Efektif: Penelitian Di Tiga Sekolah Menengah Atas', Jurnal Akuntabilitas Manajemen Pendidikan, 2.1 (2014), 44-57.
} 
intellectual in the class. ${ }^{9}$ There are some objectives in class management, those are:

a. To avoid the thing that interfere with the learning process in the class.

b. To help the students in designing time for studying and decrease the time activities that not oriented towards the objective.

c. To prevent the students from experiencing academic and emotional problems. ${ }^{10}$

According to the result of research by the Helsa and Agustina Hendriati on their journal, the factors that influence the teacher class management are the educational background, job experience, the size of homogeneity class and teacher' characteristic. ${ }^{11}$ Besides these factors, there is an important factor, namely strategy. We often hear the term "At-Thariqah Ahammu min al-Maddah". Here is the explanation of two strategies on class management. ${ }^{12}$

a. Learning Strategy I (the strategy of time improvement).

This strategy includes 1). Minimizing the time transition, a transition from the activities to another activity will have many opportunities that are fierce, such as hitting the table, shouting and more. In this case, the teacher must be able to reduce the potential for interference by avoiding the time of the transition, by preparing the students for further lesson or activity. And the teacher limits the lesson clearly. 2). Asking the students to be responsible for learning activity, by delivering the task and activity clearly, will be easy to support the students responsible. 3). Maintaining the activity flow, the strategy in the third approach can avoid the involvement of students in deviant behavior. Teachers who are not effective in doing "flip flopping".

b. Learning Strategy II (Management class strategy).

This strategy involves a). a preventive approach, this approach aims to reduce the class' problem that can disrupt the learning process. b). supportive approach, this approach aims to maintain and improve the condition of the class, c). Repair,

\footnotetext{
${ }^{9}$ Sulaiman Sulaiman, Nurmasyitah Nurmasyitah, And Others, 'Peran Guru Dalam Pelaksanaan Manajemen Kelas Di Gugus Bungong Seulangakecamatan Syiah Kualakota Banda Aceh', Jurnal Ilmiah Mahasiswa Pendidikan Guru Sekolah Dasar, 2.1 (2017).

${ }^{10}$ Saprin Saprin, 'Pengaruh Penerapan Manajemen Kelas Terhadap Peningkatan Aktivitas Belajar Peserta Didik Di Mts. Negeri Gowa', Al-Kalam, 9.2 (2017).

${ }^{11}$ Helsa Dan Agustina Hendriati, 'Kemampuan Manajemen Guru: Penelitian Tindakan Di Sekolah Dasar Dengan Ses Rendah', Jurnal Psikologi, Vol 16 (2017), P.89-104.

${ }^{12}$ Gasong.
} 
discipline, and correct (corrective approach).

\section{Arranging the Class Environment}

In arranging the class environment, there are several styles of classroom arrangement so that students are not bored in one style. Physical environment divided into 2 , those are the principal of class arrangement and class arrangement model.

a. The principle of class arrangement

1) Ensuring that the teacher is easier to see the students.

2) Ensuring the students are easier to access the lessons and equipment.

3) Reducing traffic congestion in the classroom.

4) Ensuring the students are easier to see class achievement.

b. Class Arrangement Model

There are five models of the class arrangement by several combinations. In class arrangement standard, consist of auditorium model, face to face off-set, seminar model, cluster model. ${ }^{13}$ We can consider the class arrangement model as follows: 1). Accessibility; make it easier for students to get easy tools and resources. 2). Mobility; teacher and students feel free to move from one part to another. 3). Interaction; facilitate the interaction between teacher and students. 3). Variation in students' work; the participants must cooperate with both individual or group.

When the classroom learning process must provide an effective atmosphere. Even that we know that there is no ideal form classroom. Some class arrangement models are as follows:

1. Auditorium Model is a traditional model in which the students face the teacher or whiteboard. The arrangement by this model the teacher is freer to move.

2. Face to face, in this model the students face each other. The interference in this model is greater than the auditorium model.

3. Off-set is the table arrangement by off-set style usually there are 3-4 students without facing each other. Off-set style is less interference than face to face model and this model more effective in learning.

${ }^{13}$ Tri Ujiati Syaifurrahman, Menejemen Dalam Pembelajaran (Jakarta Barat, 2013). 
4. Seminar Model, the number of students is more than off-set and face to face because of the seminar model in the form of circle, square and also U-shaped letter. It becomes more effective when the teacher wants the students doing a discussion.

Cluster discussion is a model that the number of students is consist of 4-8 students in a small group, this arrangement model is more effective for collaborative learning. The circle seat arrangement is appropriate to discussion or makes a result of work. ${ }^{14}$

\section{Method}

This research used descriptive qualitative research that were the researcher studied, explored, and exposed a social event comprehensively and deeply. ${ }^{15}$ The event that would be exposed was the description of the research in the form of phenomena and current event. ${ }^{16}$ The data that the researcher got in the form of words either express or implied from the related parties that could answer the data needed. ${ }^{17}$ This qualitative research described the strategy that used by the musyrifah when the mufrodat learning, while the object of the research was mutawassith class which Shabah al-Lughah program held in the center of Ma'had al-Jami'ah UIN Maulana Malik Ibrahim Malang. And also about how the musyrifah managed the learning process in the classroom so what the musyrifah did could improve the class management and implicate to the target intended.

The data collecting technique that used in this research were the interview, observation, and documentation in getting the data. The characteristic of the qualitative research was the human as the tool. ${ }^{18}$ The validity of the data used in this research were; first, conducted an observation while the learning process was run and then conducted an interview in order to got the data from the musyrifah. The second observation checked the effect. Third, triangulation as the validity of the data that used something else in comparing the result of analysis to the object of the research. In the analysis method of this research was used Miles dan Huberman theory. The stages involved: 1). Data

\footnotetext{
${ }^{14}$ Syaifurrahman.

15 Dzuqon Ubaidat Dkk, 'Al-Bahts A-'Ilmiy Mafhumuhu Wa Adawatuhu Wa Asaalibuhu', Riyadh (Dar Usamah Li Al-Nasyr Wa At-Tauzi', 1997), P. P.219.

${ }^{16}$ Ahmad Utsman And Abdu Al-Rahman, 'Manahij Al-Bahts Al-Ilmi Wa Thuruq Kitabah Al-Risalah AlJami Iyyah' (Sudan: Al-Khartum, 1995).

${ }^{17}$ Suharsimi Arikunto, Prosedur Penelitian Suatu Pendekatan Praktik (Jakarta: Rineka Cipta, 2013).

${ }^{18}$ Moh Kasiram, 'Metodologi Penelitian: Kualitatif--Kuantitatif' (Uin-Maliki Press, 2010).
} 
collection, 2). Data Reduction, by sorting, choosing and simplifying the data. 3). D data display, by processing the data and classifying based on the strategy of relationship patterns and the role of musyrifah in improving mutawassith class management in mufrodat, 4). The conclusion of the data percentage.

\section{Result and Discussion}

\section{Musyrifah Strategy in Mufrodat Management Class}

Based on the research that was done with the component of class management that consists of four components, namely time, place, individual and material:

a. Time Management

The time that was used on Shabah al-Lughah was 60 minutes. The detail as follows; the first 10 minutes for opening; greetings, yell, addressing by saying hello, record the attendance. The 11-17 minutes for delivering the material; musyrifah mentioned one of the mufrodat and asking the meaning of the word. Then 18-40 minutes, musyrifah mentioned the meaning randomly and followed by the mahasantri repeatedly. Then 41-50 minutes there was problems that faced by some sleepy mahasantri. The musyrifah called their names and asked them to answer the meaning of mufrodat that have been mentioned by the musyrifah and implemented the lu'bahlughawiyah. The 51-60 minutes was closing; repeated mufrodat that have been delivered by question- answer, and ended by saying thanks and apologize from the musyrifah and reciting the kafaratul majlis ${ }^{19}$.

b. Place management

There were three models of management class model in Shabah al-Lughah, they were auditorium model, face to face, and seminar. The auditorium model and seminar model were more in outdoor for making the musyrifah easier to see and pay attention to the mahasantri' activity in the class. While face to face model was more general to use when the Shabah al-Lughah class in a dormitory (indoor). This Shabah alLughah class was not used benches and chairs, and this activity generally did with the position the musyrifah stood in front of mahasantri and mahasantri sat based on management class model, when learned mufrodat was not used a whiteboard.

${ }^{19}$ Dokumentasi Observasi 7 November 2018 


\section{c. Individual Management}

The individual that involved in the class were 20 Mahasantri as the students and a musyrifah as the teacher. Musyrifah strategi in organizing individual were more dominant as teacher-centered because musyrifah was very authorized to organize mahasantri ${ }^{20}$.

d. Material and Equipment Mangement

Shabah al-Lughah material in this research focused on mufrodat material. The learning methods used in Shabah al-Lughah for mufrodat material was grammatical translation method, audiolingual method, and direct method. grammatical translation method and direct methods did because of the indoor activity, musyrifah asked to translate mufrodat and it a must to directly answer by mahasantri. While the audiolingual method used when the musyrifah asked mahasantri to listen mufrodat then imitated it. Then question- answer did by choosing some of mahasantri to answer the related questions about mufrodat that have been learned. The learning equipment was a conversation book that consists of mufrodat and it learned from each of the themes. ${ }^{21}$ While other equipment namely bithaqah media in the form of small paper that consists of mufrodat. It applied in lu'bah lughawiyah. ${ }^{22}$

Based on the result of research by analyzing 4 components of management class, whether from management time side musyrifah has been organized the time where the opening must begin then the main activity after that evaluation and the last was closing. In organizing the place, musyrifah used two locations, indoor and outdoor. At mutawassith class, a musyrifah had a lot of ways to organize class that she guided. At mutawassith class, the Shabah al-Lughah program especially for mufrodat material, there were two models of management class: auditorium model and face to face. Management class strategy was in line with some various models from 5 models of management class model according to Khoe Yao Tung ${ }^{23}$, musyrifah applied 3 models in mutawassith class on mufrodat material.

There were several strategies that used by musyrifah in delivering material in mutawassith class and Shabah al-Lughah class, that was by asking the meaning of

\footnotetext{
${ }^{20}$ Dokumentasi Wawancara 14 November 2018

${ }^{21}$ Dokumentasi Obervasi 7 November 2018

${ }^{22}$ Dokumentasi Wawancara 18 November 2018

${ }^{23}$ Gasong.
} 
mufrodat, if the students confuse to answer, musyrifah gave a motivation by giving clues in the form of gesture and synonym and antonym of words occasionally, it did by musyrifah in order to make the students could explore their ideas so they motivated and active in following the mufrodat material. The phenomena of mufrodat learning process were in line with the theory of mufrodat learning strategy on mutawassith level that initiated by Harun Baharuddin. The strategy variation that applied by musyrifah such as audiolingual method, grammatical translation method, and direct method.

Besides that, there was a musyrifah strategy in dealing with problems that occurred in learning mufrodat. For example, there was one sleepy mahasantri, and at that time musrifah rebuked her by called her name, after that musyrifah gave her motivation by inviting her to practice lu'bah lughawiyah. When there was mahasantri answered the musyrifah question about mufrodat correctly, musyrifah gave appreciation to the mahasantri, but if there was mahasantri that gave incorrect answer, musyrifah corrected it and revised the answer. Based on what the musyrifah have done in mutawassith class was appropriate with the strategy I - II theory of management class according to Khoe Yao Tung. ${ }^{24}$

\section{The Role of Musyrifah}

The role of musyrifah in Shabah al-Lughah class was as the class controller that controlled the ongoing activity in the class. Musyrifah was a tutor that has been selected and able to carry out the mandate. Musyrifah has been provided with special materials related to the activity in Shabah al-Lughah class. The components of the management class that was appropriate with the musyrifah role were as follow:

a. The role of musyrifah in managing time.

Time control that occurred in the classroom was not escaped from the role of musyrifah. Minimized the transition time that occurred so that it enough to deliver the material and mahasantri could understand and remember the material that has been learned.

b. The role of musyrifah in managing place.

The role of musyrifah in managing place was as a tutor. Musyrifah instructed and arranged seats based on the model of management class that musyrifah asked. When mahasantri sat in a place that not seen by the musyrifah because of being

${ }^{24}$ Khoe Yao Tung, Pembelajaran Dan Perkembangan Belajar. P.382-383 
blocked by a pole, she instructed mahasantri to move to the seat which musyrifah asked.

c. The role of musyrifah in individual management

The role of musyrifah in individual management was placed her self where mahasantri could focus on her and she could see mahasanti's activity in classroom. Beside that, the important role of musyrifah has finished the process of delivering the material as a tutor and mahasantri by mentioning their name and asked to answer the questions and followed the instruction from the musyrifah in learning mufrodat. ${ }^{25}$

d. The role of musyrifah in managing materials and equipment.

The role of musyrifah in managing material was by delivering mufrodat material as the facilitator of discussion to translate mufrodat that have been learned. The main equipment that used was a conversation book and stationary. The following was the classification of perspective in term of an activity that has been done in mutawassith class on mufrodat material: a. Control time and minimize transition b. Musyrifah instructs and manage the seats based on the management class model that musyrifah asked. c. Musyrifah delivers the material d. Question- answer about mufrodat and the meaning e. Musyrifah give the clues of mufrodat meaning as Teacher-centered perspective. Musyrifah led the discussion to give the meaning of mufrodat. Musyrifah divided into two groups and question- answer of mufrodat and the meaning by Learned-centered perspective.

In mufrodat learning on mutawassith class, musyrifah role was as a guide and class controller that organized the activity process. Musyrifah was a tutor that passed the selection and able to carry out the mandate. The tutor has been provided with special material related to Shabah al-Lughah class activity. In learning mufrodat, musyrifah positioned her self as a facilitator, she only directed mahasantri for knowing mufrodat meaning, she asked them to delivered the meaning of it mufrodat. It meant that musyrifah applied learner-centered perspective in mutawassith class.

Based on the result of research, it showed that mutawassith class activity on mufrodat material was more and applied in learning by using a teacher-centered

${ }^{25}$ Dokumentasi Obervasi 7 November 2018 
perspective and also implemented when mahasantri directed to do a discussion. From this, it could be believed that mufrodat learning must be effective with a diverse musyrifah strategy, it must be applied by Arabic teacher to develop the competence in teaching-learning field because the strategy was more important than the material to be delivered.

\section{Conclusion}

From the discussion above, it can be concluded that: musyrifah applyed several strategies and her role in the class was more as teacher-centered where based on Khoe You Tung it learning the teacher more authorize in organizing students and they more passive, but sometimes they would be more active in a discussion so that her role moved to learner center. The implication of this study was a teacher could apply variation strategy that was implemented by musyrifah, besides that the various arrangement of management class can make the student's activity effective in learning mufrodat so the students would enjoy and happy in learning Arabic.

\section{References}

Arfani, Junita W, And Sugiyono Sugiyono, 'Manajemen Kelas Yang Efektif: Penelitian Di Tiga Sekolah Menengah Atas', Jurnal Akuntabilitas Manajemen Pendidikan, 2 (2014), 44-57

Arikunto, Suharsimi, Prosedur Penelitian Suatu Pendekatan Praktik (Jakarta: Rineka Cipta, 2013)

Dkk, Dzuqon Ubaidat, ‘Al-Bahts A-‘Ilmiy Mafhumuhu Wa Adawatuhu Wa Asaalibuhu', Riyadh (Dar Usamah Li Al-Nasyr Wa At-Tauzi', 1997), P. P.219

Gasong, Dina, Belajar Dan Pembelajaran (Deepublish, 2018)

Helsa Dan Agustina Hendriati, 'Kemampuan Manajemen Guru: Penelitian Tindakan Di Sekolah Dasar Dengan Ses Rendah', Jurnal Psikologi, Vol 16 (2017), P.89-104

Kasiram, Moh, 'Metodologi Penelitian: Kualitatif--Kuantitatif' (Uin-Maliki Press, 2010) Mulyadi, Classroom Management (Malang: Uin-Malang Press, 2009)

Nurhadi, Nurhadi, And Maria Sanprayogi Ningsih, 'Implementasi Manajemen Kelas Di Mts Jabal Nurrohman Kasreman Kabupaten Ngawi Jawa Timur', Al-Asasiyya: Journal Of Basic Education, 2 (2017) 
Pasikha, Nok, 'Implementasi Manajemen Kelas Dalam Mengatasi Masalah Disiplin Siswa', Dialektika: Jurnal Pemikiran Dan Penelitian Pendidikan Dasar, 7 (2017), $55-67$

Rustaman, Nuryani Y, 'Perkembangan Penelitian Pembelajaran Berbasis Inkuiri Dalam Pendidikan Sains', In Makalah Dipresentasikan Dalam Seminar Nasional Ii Himpunan Ikatan Sarjada Dan Pemerhati Pendidikan Ipa Idonesia Bekerjasama Dengan Fpmipa. Universitas Pendidikan Indonesia, Bandung, 2005, Pp. 22-23

Saprin, Saprin, 'Pengaruh Penerapan Manajemen Kelas Terhadap Peningkatan Aktivitas Belajar Peserta Didik Di Mts. Negeri Gowa', Al-Kalam, 9 (2017)

Sulaiman, Sulaiman, Nurmasyitah Nurmasyitah, And Others, 'Peran Guru Dalam Pelaksanaan Manajemen Kelas Di Gugus Bungong Seulangakecamatan Syiah Kualakota Banda Aceh', Jurnal Ilmiah Mahasiswa Pendidikan Guru Sekolah Dasar, 2 (2017)

Syaifurrahman, Tri Ujiati, Menejemen Dalam Pembelajaran (Jakarta Barat, 2013)

Utsman, Ahmad, And Abdu Al-Rahman, 'Manahij Al-Bahts Al-Ilmi Wa Thuruq Kitabah Al-Risalah Al-Jami P्रyyah’ (Sudan: Al-Khartum, 1995) 